\title{
ANALISIS PENGGUNAAN INSTAGRAM SEBAGAI MEDIA PEMBELAJARAN BAHASA INGGRIS PADA PROGRAM STUDI PENDIDIKAN EKONOMI
}

\author{
LODYA SESRIYANI ${ }^{1)}$, NUR NAJIBAH SUKMAWATI ${ }^{2)}$ \\ ${ }^{1}$ Dosen Pendidikan Ekonomi Universitas Pamulang \\ ${ }^{2}$ Dosen Teknik Informatika Universitas Pamulang \\ dosen01852@unpam.ac.id ${ }^{1}$ dosen01859@unpam.ac.id ${ }^{2}$
}

\begin{abstract}
ABSTRAK
Pada revolusi industry 4.0, pendidikan tidak dapat lagi dipisahkan dari teknologi. Teknologi mempengaruhi semua aspek yang ada pada pendidikan termasuk peserta didik. Teknologi mempengaruhi bagaimana mereka melihat, mendengar, berbicara dan berkomunikasi. Penelitian ini bertujuan untuk mengetahui bagaimana penggunaan instagram pada matakuliah Bahasa Inggris Program Studi Pendidikan Ekonomi Universitas Pamulang. Subjek pada penelitian ini adalah mahasiswa semester 1 yang sedang mengambil matakuliah Bahasa Inggris. Total responden adalah 19 orang mahasiswa. Penelitian ini menggunakan interview yang bersifat terbuka, sehingga responden dapat menjawab pertanyaan wawancara dengan jelas dan lengkap sesuai dengan porsinya. Hasil penelitian menunjukkan bahwa mahasiswa mendapatkan manfaat yang sangat besar ketika belajar speaking menggunakan akun instagram mereka. Sebagian besar dari mereka menyatakan bahawa; (1) mahasiswa merasa percaya diri dalam berbicara Bahasa Inggris, (2) Mahasiswa lebih focus pada penggunaan grammar yang benar ketika berbicara, (3) Mahasiswa lebih mudah untuk mengoreksi postingan temannya, (4) negative komen yang diberikan oleh temannya memotivasi mahasiswa untuk berbicara lebih jelas dan lancar.
\end{abstract}

Kata Kunci : Bahasa Inggris, Instagram, Speaking. 


\section{PENDAHULUAN}

Internet telah mengubah cara seseorang berkomunikasi, melakukan penelitian, dan memudahkan segala akses untuk seseorang melakukan proses pembelajaran. Apabila sebelumnya seseorang harus keluar masuk perpustakaan untuk mencari informasi atau bahan belajar, sekarang seseorang hanya butuh jaringan internet untuk mengakses informasi apapun kapan saja dibutuhkan. Menggunakan teknologi bukan lagi sebuah pilihan, namun sudah menjadi kebutuhan dan keharusan.

Perkembangan teknologi yang sangat cepat berbanding lurus dengan perkembangan sosial media. Hal ini berdampak pada proses belajar peserta didik didalam kelas. Menurut McGraw- Hill, Presiden Pendidikan Tinggi, belajar secara efektif- dan dengan jenis teknologi yang tepat adalah salah satu cara terbaik untuk memastikan siswa berhasil didalam kelas, selain itu sikap fokus peserta didik juga menjadi kuncinya (Belardi, 2013).

\begin{tabular}{lcr} 
& Semakin & \multicolumn{2}{c}{ berkembangnya } \\
sosial media & dipandang & cukup \\
mempengaruhi & siswa & secara
\end{tabular}
akademik. Sosial media menjadi salah satu alternative media pembelajaran. Di dunia akademis, Social networking sites (SNS) dianggap sangat bermanfaat didalam pembelajaran bahasa karena desainnya yang berpusat pada masyarakat mendukung penyebaran bahasa asli dan mendorong interaksi yang terjadi diluar kelas.

Popularitas media sosial sangat berdampak pada peserta didik. Peserta didik lebih banyak menghabiskan waktu mereka untuk menggunakan sosial media melalui laptop maupun seluler mereka. Peserta didik bahkan memiliki akun yang mereka kelola sendiri untuk berinteraksi dengan teman- teman bahkan untuk melakukan interaksi sosial dengan orang- orang baru seluruh dunia. Oleh karena itu hal ini dapat diadaptasi oleh guru atau pendidik untuk mengembangkan kegiatan tertentu yang menggunakan sosial media dalam pembelajaran Bahasa. Guru atau pendidik dapat secara aktif menggunakan instagram untuk tetap terhubung dengan peserta didik (Zhang, 2013).

Alasan paling mendasar untuk menggunakan instagram sebagai media pembelajaran adalah karena peserta didik sudah terbiasa menggunakan instagram, lebih lagi pendidik tidak membutuhkan biaya yang besar untuk mengaplikasikannya karena hampir semua peserta didik sudah memiliki laptop dan gadget, selain itu penggunaan instagram juga tidak membutuhkan pelatihan yang khusus, sehingga mudah untuk diterapkan di jenjang pendidikan apapun.

Selain itu, ada beberapa alasan lain yang dapat dijadikan bahan pertimbangan untuk menjadikan instagram sebagai media 
pembelajaran;

pengajaran untuk

mendukung

sepanjang hayat, instagram dapat

digunakan oleh setiap jenjang

pendidikan, (2) instagram

memberikan peserta didik

kewenangan untuk membuat konten

digital sendiri dan mempublikasikannya secara online, selain itu dapat merangsang keaktifan peserta didik dan pendidik dalam pengajaran,(3)instagram

memungkinkan adanya kolaborasi antara peserta didik dan pendidik pada proyek atau tugas tertentu demi tujuan pembelajran (Bexbeti, 2014).

Peserta didik sudah siap untuk perubahan teknologi dalam belajar (Manca \& ranieri, 2013). Saat ini facebook, twitter dan Instagram adalah flatfom SNS yang paling popular. Oleh karena itu, flatfom tersebut dapat digunakan sebagai alat pembelajaran yang memberikan dampak positif pada pembelajaran bahasa.

Instagram diluncurkan pada Oktober 2010 dan perkembangannya sangat cepat, instagram dapat memperoleh satu juta pengguna hanya dengan waktu satu bulan setelah resmi diluncurkan. Pada April 2015, jumlah penggunanya sudah mencapai 300 juta pengguna aktif (Costill, 2014; instagram, 2015), pertumbuhan ini lebih cepat daripada media sosial popular lainnya seperti facebook, twitter, blog dan My Space. Indonesia merupakan peringkat ke 4 negara dengan pengguna aktif instagram terbanyak di tahun 2019 (Indonesian Digital Report, 2019). Berikut adalah negara yang menduduki peringkat 4 besar dengan jumlah pengguna instagram terbanyak di dunia yang jika diurutkan adalah: (1) Amerika Serikat total pengguna 110 juta atau 33.44 persen dari total populasi; (2) Brasil total pengguna 66 juta atau 31.38 persen dari total populasi; (3) India total pengguna 64 juta atau 4.68 persen dari total populasi; (4) Indonesia total pengguna 56 juta atau 20.97 persen dari total populasi. Di Indonesia, pengguna instagram terbanyak berasal dari rentang usia 18 tahun hingga 24 tahun untuk pria dan wanita.

Instagram memberikan peluang yang luar biasa untuk pembelajaran Bahasa bagi guru dan siswa. (Aydin, 2014 \& Campos, 2015). Instagram menyediakan cara baru untuk peserta didik belajar bahasa dan budaya secara kritis, selain itu juga membantu peserta didik untuk merefleksikan proses pembelajaran bermakna (Chun, Smith \& Kern, 2016). Melalui instagram, peserta didik dapat mempraktikkan 4 skill dalam Bahasa Inggris sekaligus.

Penelitian ini bertujuan untuk menganalisis penggunaan instagram pada Mata Kuliah Bahasa Inggris di Program Studi Pendidikan Ekonomi Universitas Pamulang. Pada Akhirnya untuk mengetahui dampak positif apa yang diperoleh mahasiswa dalam 
meningkatkan kemampuan 4 skill dalam Bahasa Inggris.

\section{METODE PENELITIAN}

Penelitian ini menggunakan metode kualitatif deskriptif. Responden yang dipilih adalah mahasiswa semester pertama Program Studi Pendidikan Ekonomi Universitas Pamulang yang sedang menjalani Matakuliah Bahasa Inggris. Responden berjumlah 19 orang yang terdiri dari satu kelas. Semua responden diberikan pertanyaan wawancara secara terbuka untuk mengetahui bagaimana penggunaan instagram dapat meningkatkan kemampuan 4 skill Bahasa Inggris.

Setelah dilakukan wawancara, peneliti melakukan focus group discussion untuk mengetahui lebih dalam lagi tentang penggunaan instagram sebagai media pembelajaran matakuliah Bahasa Inggris.

Instrument wawancara yang digunakan adalah 20 pertanyaan yang bersifat terbuka yang diberikan kepada semua responden, kemudian hasil wawancara tersebut diketik ulang dengan langkah sebagai berikut; (1) data hasil wawancara diketik dalam catatan lapangan (field note), setiap temuan direflesikan dan ditafsirkan oleh peneliti, (2) reduksi data, yaitu proses menganalisis,menyeleksi, memfokuskan dan membuang hal- hal yang tidak relevan terhadap apa yang menjadi topic penelitian, terakhir diberikan kode (coding), menyajikan data, menyusun informasi secara deskriptif atau narasi yang terkait dengan rumusan masalah penelitian ini, yaitu utnuk mengetahui penggunaan instagram dalam pembelajaran matakuliah Bahasa Inggris, (4) Menarik kesimpulan dan verifikasi.

Sebelum dilakukan wawancara, setiap mahasiswa diberikan tugas individu untuk membuat sebuah video berdurasi singkat yang kemudian di upload diakun instagram pribadi mereka. Konten yang dibuat harus menggunakan Bahasa Inggris yang benar secara grammatical, pronunciation, spelling and choice of word. Alasan mengapa konten tersebut harus diupload pada akun pribadi adalah agar mahasiswa merasa aware apabila melakukan error atau mistake pada saat berbicara Bahasa Inggris.

Setelah konten diupload pada akun pribadi mahasiswa, mereka diminta untuk menandai postingan tersebut kepada 3 orang temannya dan dosen yang mengampu Matakuliah Bahasa Inggris, postingan tersebut selanjutnya dikomentari dengan menggunakan Bahasa Inggris oleh dosen dan temannya yang sudah ditandai sebelumnya.

\section{HASIL DAN PEMBAHASAN}

Bahasa Inggris merupakan salah satu matakuliah umum yang wajib ditempuh oleh semua 
mahasiswa/I Program Studi Pendidikan Ekonomi Universitas Pamulang. Matakuliah ini memiliki bobot 2 sks dengan total pertemuan sebanyak 14 kali tatap muka dan Elearning. Matakuliah Bahasa Inggris memiliki tujuan umum yaitu memberikan general English kepada mahasiswa yang didalamnya mencakup 4 skill Bahasa Inggris; (1) reading, (2) speaking, (3) listening, (4) writing.

Penggunaan

pembelajaran instagram dilakukan pada Matakuliah Bahasa Inggris yang diberikan pada mahasiswa semester 1 Program Studi Pendidikan Ekonomi Universitas Pamulang. Pada penelitian ini, peneliti mencoba pengaplikasikan nya pada skill speaking. Setiap mahasiswa memiliki tugas individu untuk merekam sebuah video berbahasa Inggris yang mereka perankan sendiri, kemudian di upload ke akun instagram pribadi mereka. Untuk penelitian kali ini, peneliti tidak membatasi konten apa saja yang dapat di upload.

Mahasiswa dapat membuat konten puisi berbahasa inggris, tutorial berbahasa inggris, video review barang menggunakan Bahasa Inggris, dan sebagainya. Penilaian hanya sebatas vocabulary yang mereka pilih, pronunciation dan fluency. Dari 19 orang mahasiswa, berikut Tabel 1.1 daftar pilihan konten videonya:
Tabel 1.1. Daftar Pilihan Konten Vidio

\begin{tabular}{|l|l|}
\hline $\begin{array}{l}\text { Tutorial : make up, } \\
\text { programming } \\
\text { otodidak }\end{array}$ & $\begin{array}{l}10 \\
\text { mahasiswa }\end{array}$ \\
\hline $\begin{array}{l}\text { Review: games, } \\
\text { handphone }\end{array}$ & 5 mahasiswa \\
\hline Kesenian: puisi, lagu & 4 mahasiswa \\
\hline Total & $\begin{array}{l}19 \\
\text { mahasiswa }\end{array}$ \\
\hline
\end{tabular}

Dari Tabel 1.1, terlihat bahwa mahasiswa memberikan konten yang beragam untuk skill speaking mata kuliah Bahasa Inggris. Dari 19 orang mahasiswa, peneliti melakukan wawancara terhadap 10 mahasiswa secara acak untuk mengetahui manfaat atau kendala apa yang mereka temui ketika menggunakan instagram sebagai media pembelajaran speaking. Setelah dilakukan wawancara, peneliti melakukan focus group discussion dengan ke 19 mahasiswa agar mendapat jawaban yang pasti tentang penggunaan Instagram sebagai media pembelajaran.

Dari hasil wawancara dan focus group discussion yang dilakukan, peneliti menemukan bahwa : (1) Mahasiswa merasa sangat percaya diri dalam berbicara Bahasa Inggris, (2) mahasiswa lebih memperhatikan penggunaan grammar yang benar dalam berbicara, (3) mahasiswa lebih mudah mengoreksi kesalahan ucapan yang dilakukan temannya, (4) komentar negative yang diberikan temannya memotivasi 
mahasiswa untuk berbicara lebih jelas dan lancar.

\section{KESIMPULAN}

Berdasarkan hasil analisa data, dapat disimpulkan bahwa penggunaan instagram sebagai media pembelajaran matakuliah Bahasa Inggris khususnya untuk skill speaking sangat berdampak positif bagi pembelajaran mahasiwa dikelas. Instagram dapat membantu mahasiswa meningkatkan kemampuan berbicara dalam Bahasa Inggris.

Untuk itu kedepannya diharapkan pembelajaran didalam matakuliah Bahasa Inggris dapat menggunakan berbagai media atau alternative media yang bersifat digital. Selain lebih digemari mahasiswa, media digital memang sangat memberikan manfaat yang nayata dalam dunia pendidikan.

Dosen dan mahasiswa diharapkan mampu mempersiapkan diri untuk menyambut revolusi industry 4.0 yang salah satu perubahannya dapat dirasakan secara langsung adalah penggunaan teknologi disegala lini kehidupan, sehingga pemanfaatan sosial media khusunya instagram dipandang sebagai langkah awal persiapan dini untuk menyambut era tersebut.

\section{REFERENSI}

Aydin, S. 2014. Foreign language learners' interactions with their teachers on Facebook. System, 42(1), 155-163. https://doi. org/10.1016/j.system.2013.12.00 1

B. Belardi. 2013. Texting While Studying: New Study from McGraw-Hill Education Reveals That Technology Can Be Students' Best Friend and Worst Enemy. McGraw-Hill Education. Retrieved from: https://www.mheducation.com/ab out/news-room/textingwhilestudying-new-studymcgraw-hill-education-revealstechnologycan-be

Bexheti, Lejla A, Burim E. Ismaili, and Betim H. Cico. 2014. "An Analysis of Social Media Usage in Teaching and Learning: The Case of SEEU." Proceedings of the International Conference on Circuits, Systems, Signal Processing, Communications and Computer: 90-94.

Chun, D., Smith, B., \& Kern, R. 2016. Technology in language use, language teaching, and language learning. Modern Language Journal, 100, 64-80. https://doi.org/10.1111/modl.123 02

Costill, A. 2014. 30 Things you absolutely need to know about Instagram. Retrieved from http://www.searchenginejournal.c om/30-things-absolutelyneedknow- instagram/85991/

Indonesian Digital Report. 2019. Retrieved from https://andi.link/hootsuite-we- 
are-social-indonesian-digital-

report-2019/

Manca, S., \& Ranieri, M. 2013. Is it a tool suitable for learning? A critical review of the literature on Facebook as a technologyenhanced learning environment. Journal of Computer Assisted Learning, 29(6), 487-504. https://doi.org/10.1111/jcal.1200 7

Zhang, Lili. 2013. "Mobile phone teachnology engageent in EFL classroom." International Conference on Software and Computer Science (ICSECS): 171-173. 